\title{
Advances in Flood Early Warning: Ensemble Forecast, Information Dissemination and Decision-Support Systems
}

\author{
Haiyun Shi ${ }^{1,2, * \mathbb{D}}$, Erhu Du ${ }^{1,2}{ }^{\mathbb{D}}$, Suning Liu ${ }^{1,2}$ and Kwok-Wing Chau ${ }^{3}$ \\ 1 State Environmental Protection Key Laboratory of Integrated Surface Water-Groundwater Pollution Control, \\ School of Environmental Science and Engineering, Southern University of Science and Technology, \\ Shenzhen 518055, China; dueh@sustech.edu.cn (E.D.); liusn@sustech.edu.cn (S.L.) \\ 2 Guangdong Provincial Key Laboratory of Soil and Groundwater Pollution Control, \\ School of Environmental Science and Engineering, Southern University of Science and Technology, \\ Shenzhen 518055, China \\ 3 Department of Civil and Environmental Engineering, The Hong Kong Polytechnic University, Hunghom, \\ Kowloon, Hong Kong, China; dr.kwok-wing.chau@polyu.edu.hk \\ * Correspondence: shihy@sustech.edu.cn; Tel.: +86-755-88018870
}

Received: 7 August 2020; Accepted: 12 August 2020; Published: 13 August 2020

\begin{abstract}
Floods are usually highly destructive, which may cause enormous losses to lives and property. It is, therefore, important and necessary to develop effective flood early warning systems and disseminate the information to the public through various information sources, to prevent or at least mitigate the flood damages. For flood early warning, novel methods can be developed by taking advantage of the state-of-the-art techniques (e.g., ensemble forecast, numerical weather prediction, and service-oriented architecture) and data sources (e.g., social media), and such developments can offer new insights for modeling flood disasters, including facilitating more accurate forecasts, more efficient communication, and more timely evacuation. The present Special Issue aims to collect the latest methodological developments and applications in the field of flood early warning. More specifically, we collected a number of contributions dealing with: (1) an urban flash flood alert tool for megacities; (2) a copula-based bivariate flood risk assessment; and (3) an analytic hierarchy process approach to flash flood impact assessment.
\end{abstract}

Keywords: flood early warning; ensemble flood forecast; numerical weather prediction; service-oriented architecture; social media; individual behaviors; evacuation decisions

\section{Introduction to the Special Issue}

Flood is one of the most common and major devastating natural disasters around the world that can cause great losses to lives and property. In the last decade, flood has caused huge property damage (i.e., over $\$ 155$ billion) in the United States. A recent study on global-scale flood damage showed that the number of flood events, flood-related fatalities and economic losses have increased significantly since 1960s [1]. In the future, flood damages are expected to continuously increase due to population growth, economic development, urban expansion and climate change [2]. Flood prevention and emergency management have become permanent government services for many flood-prone regions worldwide [3]. In particular, it is critical to develop novel methods for flood early warning so that preventive measures can be taken to mitigate flood damages $[4,5]$.

Joint efforts from multiple interdisciplinary domains are required to make new advances in flood early warning, which include, but are not limited to, the following: (1) meteorological forecasts that can provide accurate weather prediction with sufficient lead time [6,7]; (2) land-surface modeling that 
can generate flood inundation maps to quantify the exposure to flood risk with high spatial-temporal resolutions [8,9]; and (3) information dissemination systems that can provide timely warnings to the public [10]. In addition, several studies have shown that the effectiveness of flood early warning can be noticeably affected by infrastructure development and social management systems in flood-prone areas [11,12]. With the advances in social hydrology and urban hydrology, it has been proposed that a holistic integration of social, economic and hydrological dimensions is critical for the development of effective flood early warnings [13,14].

Recent studies have offered a number of innovative advances in flood early warning. For instance, global flood hazard maps of fluvial floods were derived [15], both ground data and remote sensing data could be used as the input [16-18], a service-oriented architecture was proposed for efficient flood forecast [10], a tool for the cost-effective delineation of flood-prone areas was developed [19], and the role of social media and individual behaviors in flood evacuation processes were explored [20-22]. All these studies are valuable for enhancing our capacity to prevent or at least mitigate the damages to lives and property due to floods.

This Special Issue was proposed with the aim of collecting the latest methodological developments and applications in the field of flood early warning. Potential topics include, but are not limited to, the following: flood dynamics, mechanisms and processes; the development of methods for flood early warning, especially in ungauged basins; improvement of flood forecast and information dissemination using various information sources; new methods/techniques for flood risk analysis, vulnerability analysis and evacuation behaviors; empirical analysis of flood warnings and flood-mitigation practices during real-world flood events; etc. The collection of papers covers several of these aspects, and the contribution of each specific paper is summarized as follows.

The first paper is the one by Al-Suhili et al. [23] that introduces an urban flooding tool that couples a rainfall-runoff model with a flood-level map database to expedite the alert system process and estimate the flooded areas. The authors modeled the hydrological processes of Manhattan, New York City, USA, at a $0.30 \mathrm{~m}$ horizontal resolution, and suggested that, decisions, such as closing traffic in a particular area, can be aided by the proposed approach.

The second paper is the one by Naz et al. [24] which uses frequency analysis for flood forecast, taking the Indus River of Pakistan as the study area. The authors tested bivariate Archimedean copula-based models for flood risk analysis, and found that the return periods in a single variable analysis would give overestimated results. The outcomes could provide valuable information to managers to make better decisions on flood control.

The third paper is the one by Dano et al. [25] which applies an analytic hierarchy process (AHP) model to explore the impacts of flash flood hazards. The author utilized experts' judgments for assessing flash flood impacts and indicated that property loss and productivity loss ranked as the top two for the probability of occurrence in flash flood events. It is suggested that river management and flood early warning systems are favorable alternatives for flood impact reduction.

In conclusion, the present Special Issue provides new avenues to recognize the importance of flood early warning and a good overview of the advances in flood early warning.

Funding: This research received no external funding.

Conflicts of Interest: The authors declare no conflict of interest.

\section{References}

1. Tanoue, M.; Hirabayashi, Y.; Ikeuchi, H. Global-scale river flood vulnerability in the last 50 years. Sci. Rep. 2016, 6, 36021. [CrossRef] [PubMed]

2. Paprotny, D.; Sebastian, A.; Morales-nápoles, O. Trends in flood losses in Europe over the past 150 years. Nat. Commun. 2018, 9, 1985. [CrossRef] [PubMed]

3. Verkade, J.S.; Werner, M.G.F. Estimating the benefits of single value and probability forecasting for flood warning. Hydrol. Earth Syst. Sci. 2011, 15, 3751-3765. [CrossRef] 
4. Fotovatikhah, F.; Herrera, M.; Shamshirband, S.; Chau, K.W.; Ardabili, S.F.; Piran, M.J. Survey of Computational Intelligence as Basis to Big Flood Management: Challenges, research directions and Future Work. Eng. Appl. Comput. Fluid Mech. 2018, 12, 411-437. [CrossRef]

5. Yaseen, Z.M.; Sulainman, S.O.; Deo, R.C.; Chau, K.W. An enhanced extreme learning machine model for river flow forecasting: State-of-the-art, practical applications in water resource engineering area and future research direction. J. Hydrol. 2019, 569, 387-408. [CrossRef]

6. Arheimer, B.; Lindström, G.; Olsson, J. A systematic review of sensitivities in the Swedish flood-forecasting system. Atmos. Res. 2011, 100, 275-284. [CrossRef]

7. Moore, R.J.; Bell, V.A.; Jones, D.A. Forecasting for flood warning. Comptes Rendus Geosci. 2005, 337, $203-217$. [CrossRef]

8. Horritt, M.S.; Bates, P.D. Effects of spatial resolution on a raster based model of flood flow. J. Hydrol. 2001, 253, 239-249. [CrossRef]

9. Hunter, N.M.; Bates, P.D.; Horritt, M.S.; Wilson, M.D. Simple spatially-distributed models for predicting flood inundation: A review. Geomorphology 2007, 90, 208-225. [CrossRef]

10. Shi, H.Y.; Li, T.J.; Liu, R.H.; Chen, J.; Li, J.Y.; Zhang, A.; Wang, G.Q. A service-oriented architecture for ensemble flood forecast from numerical weather prediction. J. Hydrol. 2015, 527, 933-942. [CrossRef]

11. Grothmann, T.; Reusswig, F. People at risk of flooding: Why some residents take precautionary action while others do not. Nat. Hazards 2006, 38, 101-120. [CrossRef]

12. Tullos, D. Opinion: How to achieve better flood-risk governance in the United States. Proc. Natl. Acad. Sci. USA 2018, 115, 3731-3734. [CrossRef] [PubMed]

13. Di Baldassarre, G.; Viglione, A.; Carr, G.; Kuil, L.; Salinas, J.L.; Blöschl, G. Socio-hydrology: Conceptualising human-flood interactions. Hydrol. Earth Syst. Sci. 2013, 17, 3295-3303. [CrossRef]

14. Börner, K.; Rouse, W.B.; Trunfio, P.; Stanley, H.E. Forecasting innovations in science, technology, and education. Proc. Natl. Acad. Sci. USA 2018, 115, 12573-12581. [CrossRef] [PubMed]

15. Pappenberger, F.; Dutra, E.; Wetterhall, F.; Cloke, H.L. Deriving global flood hazard maps of fluvial floods through a physical model cascade. Hydrol. Earth Syst. Sci. 2012, 16, 4143-4156. [CrossRef]

16. Shi, H.Y.; Chen, J.; Li, T.J.; Wang, G.Q. A new method for estimation of spatially distributed rainfall through merging satellite observations, raingauge records, and terrain digital elevation model data. J. Hydro-Environ. Res. 2020, 28, 1-14. [CrossRef]

17. Shi, H.Y.; Li, T.J. Estimating hydrological parameters based on rainfall patterns in river basins with no long-term historical observations. J. Hydrol. 2017, 553, 651-661. [CrossRef]

18. Giustarini, L.; Chini, M.; Hostache, R.; Pappenberger, F.; Matgen, P. Flood hazard mapping combining hydrodynamic modeling and multi annual remote sensing data. Remote Sens. 2015, 7, 14200-14226. [CrossRef]

19. Samela, C.; Albano, R.; Sole, A.; Manfreda, S. An open source GIS software tool for cost effective delineation of flood prone areas, Computers. Environ. Urban Syst. 2018, 70, 43-52. [CrossRef]

20. Du, E.H.; Cai, X.M.; Sun, Z.Y.; Minsker, B. Exploring the Role of Social Media and Individual Behaviors in Flood Evacuation Processes: An Agent-Based Modeling Approach. Water Resour. Res. 2017, 53, 9164-9180. [CrossRef]

21. Du, E.H.; Rivera, S.; Cai, X.M.; Myers, L.; Ernest, A.; Minsker, B. Impacts of Human Behavioral Heterogeneity on the Benefits of Probabilistic Flood Warnings: An Agent-Based Modeling Framework. J. Am. Water Resour. Assoc. 2016, 53, 316-332. [CrossRef]

22. Rosser, J.F.; Leibovici, D.G.; Jackson, M.J. Rapid flood inundation mapping using social media, remote sensing and topographic data. Nat. Hazards 2017, 87, 103-120. [CrossRef]

23. Al-Suhili, R.; Cullen, C.; Khanbilvardi, R. An Urban Flash Flood Alert Tool for Megacities-Application for Manhattan, New York City, NY, USA. Hydrology 2019, 6, 56. [CrossRef]

24. Naz, S.; Ahsanuddin, M.; Inayatullah, S.; Siddiqi, T.A.; Imtiaz, M. Copula-Based Bivariate Flood Risk Assessment on Tarbela Dam, Pakistan. Hydrology 2019, 6, 79. [CrossRef]

25. Dano, U.L. Flash Flood Impact Assessment in Jeddah City: An Analytic Hierarchy Process Approach. Hydrology 2020, 7, 10. [CrossRef]

(C) 2020 by the authors. Licensee MDPI, Basel, Switzerland. This article is an open access article distributed under the terms and conditions of the Creative Commons Attribution (CC BY) license (http://creativecommons.org/licenses/by/4.0/). 